University of Pennsylvania Carey Law School

Penn Carey Law: Legal Scholarship Repository

Faculty Scholarship at Penn Carey Law

4-17-2017

\title{
Are There Really "Plenty of Shapiros Out There"? A Comment on the Courage of Norma L. Shapiro
}

Reid K. Weisbord

Rutgers University - Newark

David A. Hoffman

University of Pennsylvania Carey Law School

Follow this and additional works at: https://scholarship.law.upenn.edu/faculty_scholarship

Part of the Criminal Law Commons, Judges Commons, Law and Society Commons, Law Enforcement and Corrections Commons, Legal Biography Commons, and the Legal History Commons

\section{Repository Citation}

Weisbord, Reid K. and Hoffman, David A., "Are There Really "Plenty of Shapiros Out There"? A Comment on the Courage of Norma L. Shapiro" (2017). Faculty Scholarship at Penn Carey Law. 2094.

https://scholarship.law.upenn.edu/faculty_scholarship/2094

This Book Chapter is brought to you for free and open access by Penn Carey Law: Legal Scholarship Repository. It has been accepted for inclusion in Faculty Scholarship at Penn Carey Law by an authorized administrator of Penn Carey Law: Legal Scholarship Repository. For more information, please contact PennlawIR@law.upenn.edu. 


\title{
Are There Really "Plenty of Shapiros Out There"? A Comment on the Courage of Norma L. Shapiro
}

\author{
By Reid Kress Weisbord ${ }^{1}$ and David Hoffman ${ }^{2}$ \\ Edited Volume of Essays on Notable American Judges \\ (Kevin Peppers, ed., University of Virginia Press, forthcoming 2018)
}

\begin{abstract}
Norma Levy Shapiro, a trailblazing United States District Court Judge whose tenure on the Philadelphia federal bench spanned nearly 40 years, died July 22, 2016. This memoriam, written by two former law clerks, reflects fondly on Judge Shapiro's judicial courage to follow her conscience even when doing so required making deeply unpopular decisions. To illustrate, this memoriam examines three of Judge Shapiro's most memorable cases from her notable prisoner litigation docket.

First, in Harris v. Pernsley, Judge Shapiro's principled but polarizing decisions in the Philadelphia prison overcrowding litigation elicited a now-familiar brand of snark from one (tremendous! but imperfectly informed) commentator, who warned readers: "Unfortunately, there are plenty of Shapiros out there, which is one major reason why our streets are full of dangerous convicts." Despite frequent and equally hostile commentary from the Philadelphia press, Judge Shapiro's handling of the case brought about the closure of a notoriously derelict prison and the construction of new criminal justice facilities in Philadelphia. Second, in Chadwick v. Janecka, Judge Shapiro ruled unconstitutional the indefinite detention of a petitioner who refused to repatriate hidden offshore assets in a divorce proceeding. After reversal on appeal in an opinion written by then-Judge (now Supreme Court Justice Samuel Alito), the petitioner went on to serve a record-breaking term of incarceration for civil contempt (14 years). Third, in Evans v. Beard, Judge Shapiro held that principles of finality prevailed over the state's interest in the
\end{abstract}

${ }^{1}$ Vice Dean, Professor of Law, and Judge Norma L. Shapiro Scholar, Rutgers Law School

2 Professor of Law, University of Pennsylvania Law School 
belated correction of an erroneously lenient sentence 11 years after it had been imposed.

Judge Shapiro always followed her conscience along the difficult path to justice and exhibited rare courage to do what was right. If there are, indeed, "plenty of Shapiros out there," the world would be more just. But alas, there aren't, and there never were.

We former law clerks submit this tribute in memory of the late United States District Court Judge Norma Levy Shapiro, a judicial luminary of nearly forty years on Philadelphia's storied federal bench. We take joy in knowing that much was written in praise of Judge Shapiro during her life and we incorporate by reference the extensive record of her countless accomplishments and trailblazing firsts. ${ }^{3}$ But we begin not with praise, but with the words of one (tremendous!) observer-writing in 2000-on how the Judge handled her most famous case: Harris v. Pernsley. 4

Criminals are often returned to society because of forgiving judges. This has to stop. A judge who decides unilaterally to reduce sentences can cause immediate damage to a community if he or she releases dangerous criminals from jail. That's why we need to hold judges more accountable, and the best way to make that happen is to elect them. When they hurt us, we need to make sure we can vote them out of the job.

Think what wonders a public vote would work on the career of Norma Shapiro, a district court judge in Pennsylvania who was appointed by President Jimmy Carter. I think Carter has

\footnotetext{
${ }^{3}$ See, e.g., Sandra Day O'Connor, Lending Light to Countless Lamps: A Tribute to Judge Norma Levy Shapiro, 152 U. Pa. L. Rev. 1 (2003); Edward R. Becker, Tribute to Judge Norma Levy Shapiro, 152 U. Pa. L. Rev. 5 (2003); Louis H. Pollak, Norma Levy Shapiro, 152 U. Pa. L. Rev. 9 (2003); Anita B. Brody, Norma Levy Shapiro, 152 U. Pa. L. Rev. 15 (2003); Jerome J. Shestack, Tribute to Judge Norma L. Shapiro, 152 U. Pa. L. Rev. 21 (2003); Ellen P. Goodman, Tender Justice: Judge Norma Levy Shapiro's Hard-Headed Humanity, 152 U. Pa. L. Rev. 25 (2003).

${ }^{4}$ Harris v. Pernsley, 654 F. Supp. 1042, 1047 (E.D. Pa. 1987).
} 
done a lot for the world, but Judge Norma Shapiro was not his most brilliant appointment.

Shapiro once ordered the release of six hundred prisoners, apparently because she thought prisons were getting too crowded. I should add that she ordered the release of six hundred prisoners per week. Guess what happened next.

As reported in Crime: Turning the Tide in America, the U.S. Senate brought in witnesses in June 1997 to find out the extent of the disaster Judge Shapiro had created. They described a nightmare. One witness told the Senate Judiciary Committee that during one eighteen-month period after Shapiro's jailbreak, the released convicts committed nearly ten thousand crimes, including seventy-nine murders, ninety rapes, and hundreds of other violent crimes. One victim, Daniel Boyle, was a twenty-one-year-old Philadelphia police officer. From 1988 to 1992, 20 percent of thugs arrested for killing cops were out of probation or parole. In my opinion, Judge Shapiro was a willing accessory to all those crimes.

Unfortunately, there are plenty of Shapiros out there, which is one major reason why our streets are full of dangerous convicts. ${ }^{5}$

Who "wrote" this passage?

Donald J. Trump.

This account of Judge Shapiro's conduct during Harris contains several "alternative facts." 6 But we use it to frame this memoriam because it

${ }^{5}$ Donald Trump, The America We Deserve [Kindle Loc. 1184-85] (Renaissance Book 2000).

${ }^{6}$ Among them (and excluding the case's origin and history, which we will discuss in the text): the Senate Judiciary Committee hearing was held in June 1998, not 1997; the "witness" testimony before the Judiciary Committee appears to refer to remarks made by Senator Orin Hatch during a debate about the Judicial Improvement Act of 1998; and, in Hatch's account, the number of inmates released was 500, not 600, per week. 144 Cong. Rec. S6181-04, 144 Cong. Rec. S6181-04, S6188, 1998 WL 306901. Fifteen years after publication of President Trump's comments, the death sentence of the defendant convicted in the murder of Police Officer Daniel Boyle was commuted based on evidence of the defendant's severe intellectual disability. Commonwealth v. Bracey, 117 A.3d 270 (Pa. 2015). To be fair to President Trump, 
sheds light on a crucial aspect of her judicial personality and approach to judging. Consider, for a moment, the oddity that a district judge had such a profound, and controversial, impact on the public debate that Donald Trump, of all people, attacked her years before he was a national political figure. For literally decades, Norma Shapiro was among the most controversial and polarizing federal trial judges in the nation, and for almost all that time, she was on the receiving end of attacks like Trump's-some couched more formally, others more obscenely. She rarely, if ever, responded to such criticisms in public, though they wounded her. Rather, she stood her ground, and persevered.

It takes rare guts to stick to your principles given such headwinds. We organize our comments around those guts-to provide particular examples of Judge Shapiro's courage in action.

Of the thousands of matters before her court, this narrative selects three memorable cases that we believe exemplify Judge Shapiro's ability and willingness to accept public criticism when she believed justice required an unpopular decision. Judge Shapiro never viewed herself as a reformer of the criminal justice system. Indeed, she was known to heap scorn on those that expected her to articulate a judicial philosophy. "My job is to resolve cases!" she'd exclaim. And yet, many of her most notable decisions had a profoundly positive effect on criminal adjudication and corrections law. So our focus is on her prisoner litigation docket, though she was equally if not more interested in civil law.

In each of the following three cases, Judge Shapiro found the state had violated the Constitution and she ordered some or all of parties released from prison. In each case, Judge Shapiro assumed the risk of reversal and the boomerang of public criticism for making a unpopular decision necessary to prevent other branches of government from abusing power. We hope this narrative will outline a rough sketch of Judge Shapiro's constitutional philosophy, capture the essence of her compassionate and courageous approach to criminal justice, and impart her belief in the

we're quite sure he probably didn't read, and certainly didn't write, the passage, at least not unilaterally. 
importance of judicial independence as safe harbor for courts to operate free from external interference.

\section{Harris v. Pernsley: The Philadelphia Prison Overcrowding Litigation}

We begin with Harris, the controversial case for which Judge Shapiro reluctantly attracted perhaps the most national attention. We refer to Harris as shorthand for decades of litigation before Judge Shapiro in which inmates challenged the problem of endemic overcrowding in the Philadelphia prison system.

Harris found its origins in Pennsylvania's state courts. In 1971, the Pennsylvania Supreme Court described the condition of Philadelphia's prisons as dangerous if not uninhabitable:

"[T] he living conditions at Holmesburg [Prison, in particular, were] disgusting and degrading. The cells, originally built (between 1896 and 1920) to house one man, were seriously overcrowded. The physical condition of the cells is most unwholesome. Rainwater leaks into the cells through the skylights when it rains, soaking the bed coverings. The cells are infested with cockroaches and sometimes rats. Blankets, kept for six months at a time, become filthy. Prisoners charged with serious crimes may and frequently are confined with prisoners charged with much lesser offenses."7

For years, inmates had claimed such conditions violated the Eighth Amendment's prohibition of cruel and unusual punishment. ${ }^{8}$ In the 1970s, the state courts repeatedly ordered the City to correct the problem to no avail. ${ }^{9}$ State courts approved a series of consent decrees mandating reform, and, without success, appointed a special master to supervise the implementation of injunctive relief. ${ }^{10}$ The City, citing lack of resources and

\footnotetext{
${ }^{7}$ Commonwealth ex rel. Bryant v. Hendrick, 280 A.2d 110, 115 (Pa. 1971) (internal quotations omitted).

${ }^{8}$ Id.

${ }^{9}$ Id.

${ }^{10}$ Jackson v. Hendrick, 321 A.2d 603, 604 (Pa. 1974).
} 
the enormous cost of reform, refused to act so the problem continued unabated.

In 1982, Judge Shapiro was randomly assigned a class action filed by inmates housed at the notorious Holmesberg Prison. ${ }^{11}$ Philadelphia and the Commonwealth, jointly moving to dismiss, relied on doctrines of res judicata, the $11^{\text {th }}$ amendment, and federalist deference to pending state court proceedings. Judge Shapiro agreed and dismissed the case on those grounds. The Third Circuit reversed, over a dissent by Judge Garth. ${ }^{12}$ The defendants petitioned for rehearing en banc. Five of eleven judges voted to rehear the case, which was one short of the majority required. ${ }^{13}$ The Supreme Court denied a petition for certiorari over the votes of three Justices, Berger, Rehnquist, and O'Connor, who would have granted it. Chief Justice Burger, in a rare written dissent on certiorari, stated that he would reverse the Third Circuit, which had, in turn, reversed Judge Shapiro. ${ }^{14}$

We dilate on this procedure only to show how reluctant Judge Shapiro was to take on Harris. When it was forced back on her docket, she tried to settle the dispute. In 1986, following a series of hard fought negotiations, and over the District Attorney's staunch objection, the City settled the matter by consent decree. ${ }^{15}$ The court-approved settlement agreement imposed flexible caps on the City's maximum inmate capacity and required the construction of new detention facilities over a multi-year period. To ensure compliance, the consent decree included an inmate release provision that soon became the most controversial aspect of the proceeding:

"If the population of any facility still exceeds its maximum allowable population twenty-one (21) days from the date on which the maximum allowable population has been exceeded for more than seven (7) consecutive days or for more than

\footnotetext{
11 Harris v. Pernsley, 755 F.2d 338, 341 (3d Cir. 1985).

12 Judge Lenard I. Garth, a judicial giant on the Third Circuit, died September 22, 2016, two months after Judge Shapiro.

13 Harris v. Pernsley, 758 F.2d 83 (3d Cir. 1985).

14 Pernsley v. Harris, 474 U.S. 965 (1985).

15 Harris v. Pernsley, 654 F. Supp. 1042, 1047 (E.D. Pa. 1987).
} 
twenty (20) out of forty (40) days, a bar on admission of prisoners to such facility or facilities will go into effect. The bar on additional inmates will continue until the number of inmates housed is within the maximum allowable population and new admissions will not cause the maximum allowable population to be exceeded, except that persons charged with, or convicted of, murder, forcible rape, or a crime involving the use of a knife or firearm during the commission of an aggravated assault or robbery, may always be admitted notwithstanding this bar." 16

As a direct result of the consent decrees approved by Judge Shapiro, the City eventually closed the Holmesberg Prison and made good on its promise to build new detention facilities to relieve the problem of overcrowding. ${ }^{17}$ But those improvements were hard fought and took decades to achieve. In the meantime, the City's delay in carrying out its obligations triggered the court's requirement to release inmates who would otherwise have remained in detention. Judge Shapiro was subject to an unrelenting, decade-long campaign, to pressure her to change her mind and permit the City to back out of its settlement. The Philadelphia Daily News famously ran daily stories (and a sidebar) about the "victims" of Judge Shapiro's orders:

16 Id.

17 Harris v. City of Phila., CIVIL ACTION NO. 82-1847, 2000 U.S. Dist. LEXIS 12579, at *8 (E.D. Pa. Aug. 30, 2000). 
Figure 1: Daily News Articles on the "Prison Cap" Litigation, Courtesy of the Archives of the Honorable Norma L. Shapiro, Biddle Library, University of Pennsylvania
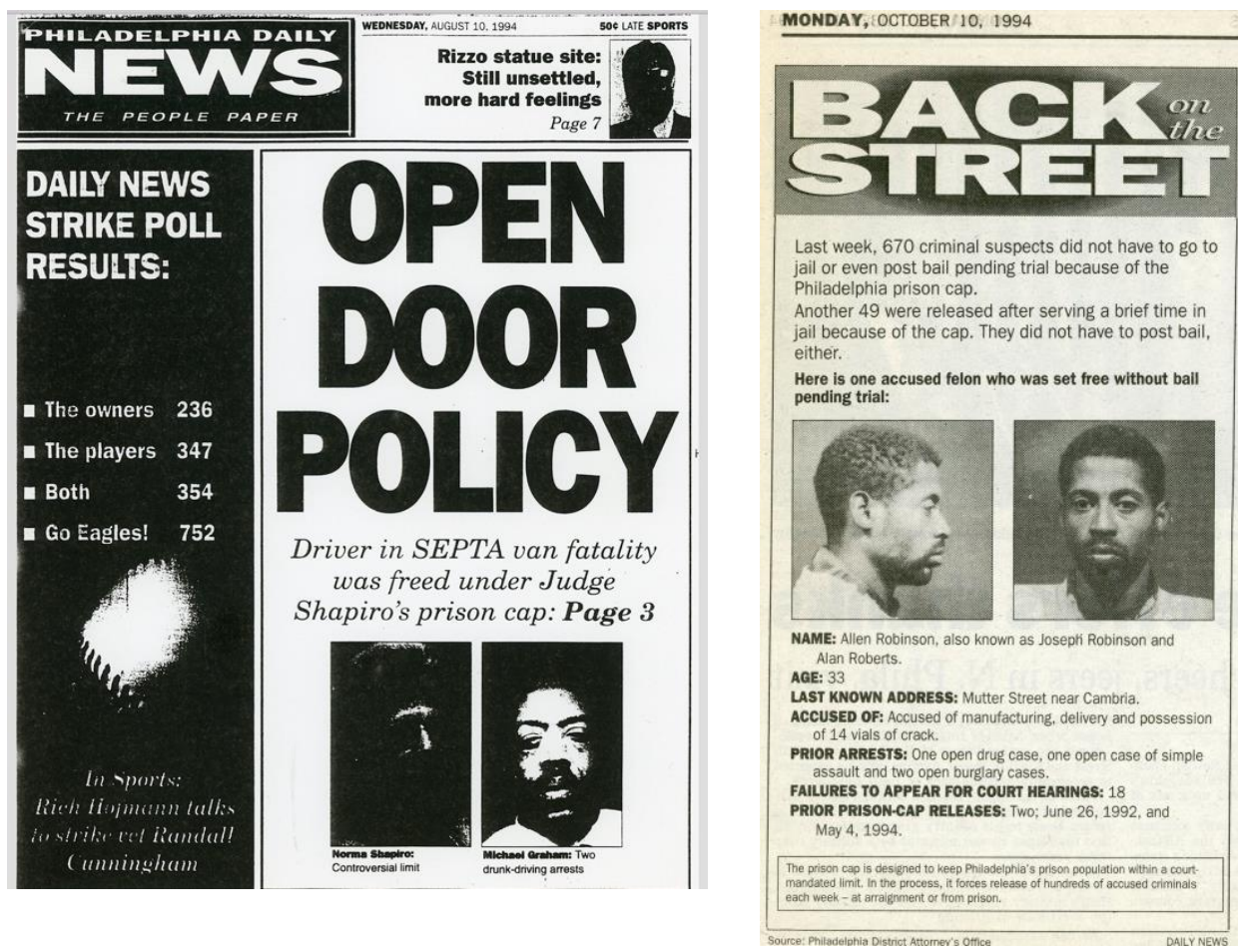

Imagine, if you will, the kind of pressure that such press exerted. And yet, from our perspective, permitting the City to escape the consequences of its own contractual commitments would have been worse. It would have immunized the legislative and executive branches from the consequences of their own mismanagement. Judge Shapiro believed in honoring commitments. So, rather than walk away, Judge Shapiro dug in. She continued to exercise supervisory authority over the prison system until new facilities were in place, and the underlying constitutional infirmities, at least temporarily, cured.

President Trump was but one of many harsh critics of Judge Shapiro for enforcing the inmate release provision. To be clear, judges are not-nor should they be-immune from criticism for their decisions and they remain bound by an ethical obligation to refrain from responding, even when 
targeted unfairly. ${ }^{18}$ Judge Shapiro certainly did not agree with critics who used her as a scapegoat for the broader problems of crime and mass incarceration, but she understood that public rebuke was often an occupational hazard for judges compelled by their conscience and the Constitution to make deeply unpopular decisions.

\section{Chadwick v. Janecka: Fourteen Years of Civil Contempt}

Our second selection is the curious case of Chadwick v. Janecka. ${ }^{19}$ Chadwick arose from a bitter state court divorce, commenced in 1992, between Beatty Chadwick and his estranged wife Barbara. ${ }^{20}$ Their marital estate included $\$ 2.5$ million in assets under Beatty's control and, after Barbara filed for divorce, Beatty offshored those assets to a Gibraltar account. Beatty claimed he transferred the funds to repay a foreign debt, but Barbara alleged that the transfers were a sham to defraud her of an equitable distribution. ${ }^{21}$ In 1995, Beatty fled the jurisdiction, but was apprehended shortly thereafter. The state court ordered him detained for civil contempt until he complied with the court's order to repatriate his assets. Beatty argued that compliance was impossible because he no longer owned the assets, but the state court did not believe him. Beatty therefore began serving what would become the longest term of incarceration for civil contempt in U.S. history.

Claiming that his indefinite detention without a criminal charge violated constitutional due process, Beatty filed a flurry of serial habeas petitions: six in state and five in federal court. His case arrived again before Judge Shapiro on the terminal (fifth) federal petition in 2000. There, Beatty argued that the purpose of civil contempt is to exact compliance with a court

${ }^{18}$ Code of Conduct for United States Judges, Cannon 2A ("A judge must expect to be the subject of constant public scrutiny and accept freely and willingly restrictions that might be viewed as burdensome by the ordinary citizen.").

${ }^{19}$ Chadwick v. Janecka, No. CIV.A. 00-1130, 2002 WL 12292, at*1 (E.D. Pa. Jan. 3, 2002).

${ }^{20}$ Chadwick v. Janecka, 312 F.3d 597 (3d Cir. 2002).

${ }^{21}$ Id. 
order rather than to punish and, because the contempt order failed to compel compliance, his continued detention was unlawful. ${ }^{22}$

Judge Shapiro found herself presiding over what appeared to be a convincing legal argument made by a highly unsympathetic inmate seeking release from prison. How could a man be imprisoned indefinitely for years without an adjudication of his guilt beyond a reasonable doubt? One the one hand, the state courts had repeatedly found that Beatty was hiding assets offshore and, if true, he was committing a fraud on his wife and the court to avoid dividing marital assets equitably in divorce. ${ }^{23}$ On the other hand, he had already served more time for civil contempt than he likely would have for theft of the same assets. His obduracy suggested either that he didn't have the money, or his will to keep it was as ironclad as the bars of his jail cell.

Knowing full-well the high risk of reversal in granting habeas relief,24 and disbelieving his impossibility defense, Judge Shapiro nonetheless ruled in Beatty's favor. ${ }^{25}$ She concluded that continued detention was futile because he would not bend to the State Court's power:

“After what is now nearly seven years' incarceration for failure to comply, there is a serious question whether confinement is still serving a coercive purpose. After this significant period of time, there

22 Id. at $* 4$.

23 Id. at *7 ("State courts have repeatedly found that Chadwick has the present ability to comply with the order to remit marital assets to a court escrow account for equitable distribution.").

24 The exceedingly high standard imposed upon petitioners seeking habeas relief in federal court makes it particularly easy for courts of appeal to overturn the grant of habeas relief by a district court and all district court judges know it. C.f., Chadwick v. Janecka, 312 F.3d 597, 605 (3d Cir. 2002) ("Under 28 U.S.C. § 2254(d)(1), if a state prisoner's habeas claim 'was adjudicated on the merits in State court proceedings,' [the appellate] standard of review is narrow: we may not reverse 'unless the adjudication of the claim ... resulted in a decision that was contrary to, or involved an unreasonable application of, clearly established Federal Law ....'”).

25 Id. ("The duration of Chadwick's incarceration has always been up to him; compliance with the state court order would guarantee his release. [....] This court is convinced that Chadwick has the present ability to comply with the July 22, 1994 order."). 
exists more than Chadwick's mere assertion that further confinement will not coerce compliance."26

Consider for a moment how difficult this must have been for someone with Judge Shapiro's convictions to write. Here was an early, trailblazing feminist, and lifelong believer in the power of courts to coerce righteous conduct (as Harris shows!), letting a fraudster free, because she thought it was the right thing to do. ${ }^{27}$

Barbara, alongside the state, appealed the grant of habeas relief and, although not unforeseen, the Court of Appeals reversed. Writing for the appellate panel, then-Circuit Judge (now Supreme Court Justice) Samuel Alito found that the exactingly high standard for habeas relief could not be satisfied by establishing that Beatty had "no substantial likelihood" of complying. ${ }^{28}$ The Third Circuit noted that, in International Union $v$. Bagwell, ${ }^{29}$ the Supreme Court "seems to permit a contemnor who had the ability to comply with the underlying court order to be confined until he or she complies." 30 The panel therefore concluded that, "if this reading is correct, Bagwell directly contradicts the decision of the District Court in the present case." 31 Thus, after winning in the district court, Beatty had lost on appeal and went on to serve another seven years in state prison. Notably,

\footnotetext{
${ }^{26}$ Id.

27 We digress briefly here to note that Judge Shapiro's outspoken passion for advancing the role of women in the law was always matched by her quiet, but equally meaningful and important, acts of professional courage. Novelist Magdalen Braden was at 38 the oldest student in her third year class at Penn Law in 1994. In part because of the age differential, Ms. Braden found herself having trouble finding legal employment for after graduation. Judge Shapiro, whom Braden had met at the Penn Inn of Court, recognized Braden's sharp legal mind and untapped talent. Judge Shapiro not only hired Braden as a law clerk but also ensured that the Judge's former law firm, then known as Dechert Price and Rhodes, gave Braden proper consideration in its hiring process. Braden credits Judge Shapiro's role in landing a partner-track associate position at Dechert. There are, no doubt, countless other talented lawyers for whom Judge Shapiro played a similarly quiet role in promoting their careers and, in so doing, diversity of the legal profession.

${ }^{28}$ Chadwick v. Janecka, 312 F.3d 597, 613 (3d Cir. 2002).

${ }^{29}$ International Union v. Bagwell, 512 U.S. 821, 828 (1994).

${ }^{30}$ Id. at 608 (citing International Union v. Bagwell, 512 U.S. 821, 828 (1994)).

$31 \mathrm{Id}$.
} 
although the Third Circuit reversed, it did so with great apparent appreciation for Judge Shapiro's meticulous work on the case below.

For any self-respecting trial judge, reversal on appeal is typically a poignant moment of professional disappointment. This was especially true of Judge Shapiro, who took great pride in the painstaking quality of her opinions, which remain widely admired for their logical coherence and exceptional clarity. We select this case from the thousands of Shapiro's opinions, not to highlight a moment of defeat (and consequent discussions with a former clerk at a judicial reunion) but because it illustrates her elegant view of the Constitution as supremely above the fray of rough justice. Beatty's defense was repeatedly discredited by the state court and surely he did not deserve to be rewarded with habeas relief for performing a legal stunt to defraud his wife of martial assets. Had Beatty been charged with a criminal offense and sentenced to imprisonment following a lawful conviction, we have no doubt that Judge Shapiro would have decided the case differently. But Beatty was not charged with any crime. Thus, lurking in the ether of Judge Shapiro's opinion is a profound but simple notion of constitutional due process: the state's power to detain a person indefinitely in the absence of a criminal charge cannot be justified by the detainee's conduct, no matter how unsavory or distasteful, without first obtaining a lawful conviction.

Chadwick also exemplifies the enduring wisdom of Judge Shapiro's legal instincts, even though her uncanny judicial foresight did not become evident until long after her ruling was reversed on appeal. As it turns out, Judge Shapiro was right all along: the state's indefinite detention of Beatty Chadwick was not an effective sanction to coerce him into compliance. In 2009 , another seven years after the Third Circuit ruled that Beatty could be detained indefinitely, and after he had achieved the distinction of setting a record for civil contempt detention in the United States, the Pennsylvania state court finally released Beatty for precisely the same reasons that Judge Shapiro articulated in 2002.32 It held that Beatty had the ability to comply

${ }^{32}$ Indeed, the Third Circuit, too, set the stage for the state court's reconsideration. Chadwick v. Janecka, 312 F.3d 597, 614 (3d Cir. 2002) ("needless to say, our decision imposes no restrictions on the state courts' ability to grant relief"). 
with the order to repatriate his assets, but the sanction had lost its coercive effect and, consequently, his continued detention had become punitive. ${ }^{33}$ It also seems that Judge Shapiro's skepticism of Beatty's story about the missing offshore assets was well-founded. In 2010, a reporter for the Philadelphia Inquirer found that Beatty had created an online dating profile describing himself as a bachelor with expensive taste (subscriptions to the orchestra, ballet, opera, and theater; a passion for European travel and wine tasting). ${ }^{34}$ Beatty might have added: here's a man who can hold grudge!

\section{Evans v. Beard: A State Court Sentencing Error Corrected 11 Years Later}

Our third and final case is Evans v. Beard, a habeas petition brought by William Evans, a state prisoner convicted on multiple counts of incest and the rape of young children. ${ }^{35}$ At the outset, we acknowledge that the crimes committed by Mr. Evans distinguish him as, by far, the least sympathetic petitioner featured in this memoriam. Recognizing the severity of his crimes, one of the state courts sentenced Mr. Evans to more than 700 years' imprisonment. However, that sentence was later vacated on appeal in an exceptionally complex multi-jurisdictional state court procedural history that we need not recount here. For our purposes, it is sufficient to note that the Mr. Evans began his incarceration in 1986 and, in 1994, his 700-year sentenced was reduced to 10 to 20 years' imprisonment.

Throughout his sentence, Mr. Evans received annual correspondence from the Pennsylvania Board of Probation and Parole stating that he would

${ }^{33}$ See Mari A. Schaefer, Chadwick freed after 14-year contempt sentence, The Philadelphia Inquirer at A1 (July 11, 2009).

${ }^{34}$ Monica Yant Kinney, Beatty Chadwick, trolling Match.com, still defying truth, The Philadelphia Inquirer at A1 (Nov. 10, 2010). Although Judge Shapiro probably never actually saw Beatty's online profile, she was keenly aware of what was happening on the Internet. Former clerk Michelle Ryan Scharfenberg describes Judge Shapiro's admonition on the use of courthouse computers: "I joined Chambers in fall 1998, a time when the internet was just starting to become something. On one of my first days there, my co-clerk and I were sitting at our desks and the judge walked in and faced us and said 'Don't use the computer to look up porn.' And that was the extent of my 'computer training' for the job. I was both a little shocked and amused by her 'training."'

35 Evans v. Beard, 639 F. Supp. 2d 497 (E.D. Pa. 2009). 
be released on November 13, 2006. But in April 2005, shortly before his anticipated release, Mr. Evans received a different notice. This time, the Board informed him that it had added four and a half years to his sentence because, in the 1994 re-sentencing hearing, the state court judge improperly computed credit for time served. ${ }^{36}$

As it turns out, the 2005 notice was correct about the sentencing judge's erroneous computation. Mr. Evans had been convicted in separate proceedings in two Pennsylvania counties. This fact was significant because state law precluded the grant of credit for time served on a prior unrelated sentence before the effective date of a subsequently imposed concurrent sentence. ${ }^{37}$ The problem in Mr. Evans' view, however, was that the state waited almost 11 years to correct the error and, when it finally issued a correction, the judge signed a new sentence without notice to Mr. Evans or an opportunity to be heard. Mr. Evans filed a federal habeas petition randomly assigned to Judge Shapiro.

We surmise that, had Judge Shapiro presided over the original resentencing of Mr. Evans, she would have imposed a harsher punishment than 10 to 20 years because of the extraordinary severity of his crimes. But the wisdom of the state court's resentencing decision of 10 to 20 years was not the subject of her review. Rather, the question presented was whether the state could correct an erroneously lenient sentence nearly 11 years after its imposition.

Judge Shapiro concluded (courageously, in our view) that, notwithstanding the horribleness of what brought Mr. Evans into the criminal justice system, the state's mishandling of the sentence shocked the conscience and therefore violated his right to substantive due process. The District Court opinion explained:

"The Department of Corrections' gross delay in seeking the state court's correction of Evans' Form DC-300B was fundamentally unfair, as was the court's decision to grant the amendment. As early as 1994, the Department of Corrections

${ }^{36}$ Id. at 501.

37 Id. at 499-500. 
had actual knowledge that Form DC-300B granted Evans more credit than it believed was allowed under state law. After the Clerk of Court certified Form DC-300B granting the contested credit over the Department's objection in February 1995, the Department abandoned the issue for more than a decade. In 2005, eleven years after the sentence was imposed and Evans had exhausted his appeal (and just one year before his scheduled release), the Department renewed its effort to remove the time credit. The Department's prolonged delay in seeking correction of Form DC-300B is shocking to the conscience; so was the court's decision to grant the amendment. If the Fourteenth Amendment Due Process Clause imposes a temporal limit on the power of a sentencing court to correct an illegal sentence, an eleven year delay by the Lehigh County Court of Common Pleas certainly exceeded that limit."38

Fully aware of the strong likelihood of reversal in cases like this, Judge Shapiro nevertheless granted Mr. Evans' habeas petition because she believed the Constitution required it. Anticipating the district attorney's response, however, Judge Shapiro ordered that Mr. Evans' release be postponed for 30 days to give the state an opportunity to file an appeal. ${ }^{39}$ The state filed a timely appeal and, as a further precaution, Judge Shapiro yielded the decision of whether to stay Mr. Evans' release pending appeal to the Third Circuit. On the state's emergency motion, a two-judge motions panel of the Third Circuit denied the stay. ${ }^{40} \mathrm{Mr}$. Evans was now a free man.

Mr. Evans' release from prison quickly attracted media attention. A Philadelphia television station, 6ABC Action News, covered the story on the local evening news with the headline, "CONVICTED CHILD RAPIST

\footnotetext{
38 Id. at 508-09.

39 By that point, Mr. Evans had served more than two and a half years beyond his original 2006 release date.

40 Order at 1, Evans v. Beard, No. 09-2657 (3d Cir. June 26, 2009) ("The forgoing motion for a stay is denied.").
} 
RELEASED EARLY." 41 The reporter interviewed the local District Attorney, who characterized the problem in Mr. Evans' resentencing as a "clerical error." This, of course, was true, but incomplete. The sentencing judge's clerical error was not the aspect of Mr. Evans' proceeding found by Judge Shapiro to violate substantive due process; it was the state's gross delay in correcting it. The reporter also interviewed a children's rights advocate who worried that Mr. Evans' release would discourage young victims of rape and sexual abuse from seeking help. ${ }^{42}$ We share the advocate's concern about the problem of underreported child abuse, but it is difficult to identify a direct link between that problem and Mr. Evans' case. By the time of his release, Mr. Evans had already served more than half of the additional four years added by the belated correction of his sentence.

Nearly two years following Mr. Evans' release, the Third Circuit reversed the District Court's grant of habeas relief.43 Writing for the Third Circuit, however, Judge Kent Jordan was deliberately measured in expressing disagreement. Indeed, the carefully worded opinion appears as if it were drafted to emote the panel's great respect for Judge Shapiro and her legal analysis. Judge Jordan repeatedly emphasized the "amorphous character of the shock-the-conscience test," 44 and offered the uncommonly disarming concession that " $[\mathrm{w}]$ hat is shocking to the conscience inevitably depends to a degree on whose conscience is being tested; so, to put it mildly, the standard has some give in it." 45 Judge Jordan's words are a rare public acknowledgement that, although reversed, Judge Shapiro was not mistaken in her analysis, but that reasonable minds simply differ in applying a weakly defined constitutional due process standard.

We select this case to remember Judge Shapiro, again, not to revisit the disappointment felt by all trial judges when an opinion is reversed on appeal. Rather, this case presents a compelling illustration of Judge

41 Walter Perez, CONVICTED CHILD RAPIST RELEASED EARLY, 6abc Action News (June 30, 2009) available at http://6abc.com/archive/6892312/.

42 Id.

${ }^{43}$ Evans v. Sec'y Pa. Dep't of Corr., 645 F.3d 650, 652 (3d Cir. 2011).

${ }^{44}$ Id. at 661.

${ }^{45}$ Id. at 660 . For an alternative theory of habeas relief on Double Jeopardy grounds, see Reid K. Weisbord \& George C. Thomas, III, Judicial Sentencing Error and the Constitution, 96 B.U. L. Rev. 1617, 1652 (2016). 
Shapiro's steadfast unwillingness to follow the path of least resistance when confronted by a challenging or controversial matter. In Evans, Judge Shapiro could have easily disposed of the case by curtly adopting the magistrate's Report and Recommendation against granting relief. Such a ruling would all but guarantee affirmance on appeal. But Judge Shapiro assumed the risk of reversal in making the harder decision to grant habeas relief because, to her, the state's mishandling of Evans' sentence was not a harmless clerical error, as argued by the District Attorney. To the contrary, the state's gross delay in correcting an erroneously lenient sentence inflicted a significant, though intangible, harm that implicated the venerable constitutional protection of substantive due process.

These three cases can be variously described. For some, they might suggest a district judge unwilling to bend to hierarchical authority, and consequently a rogue agent within the federal judiciary. That's not what we see. We see a woman with rare courage to do what was right, who tried to push all those she came in contact with-the lawyers and citizens who appeared before her, the appellate judges who sat above her, her colleagues on the bench, and her clerks - to a path of righteous justice. It takes guts to be accused of being an accomplice to murder by your City's paper, and it takes just as much to order the release of guilty men. That's true even when you are convinced it's the right thing to do. Donald Trump, for whatever his other virtues and political instincts, got the gist of our former boss all wrong. There are not "plenty of Shapiros out there," and there never were. 